\title{
Microhardness and Diametral Compression Strength of Single Fill Composite
}

\author{
Microdureza y Resistencia a la Compresión Diametral \\ de Resina Compuesta Mono Incremental
}

\begin{abstract}
Ricardo Huver de Jesus'; Kalenna Soriano Lage²; Valéria Chiabai Dalboni²; Ornella Luisa Delboni²; Jefferson David Melo de Matos ${ }^{3}$; Leonardo Jiro Nomura Nakano ${ }^{3}$; Laura Patricia Nadal Ortiz ; John Eversong Lucena de Vasconcelos ${ }^{4}$; Marco Antonio Bottino ${ }^{3}$ \& Lucas Campagnaro Maciel ${ }^{1}$
\end{abstract}

DE JESUS, R. H.; LAGE, K. S.; DALBONI, V. C.; DELBONI, O. L.; MATOS, J. D. M.; NAKANO, L. J. N.; ORTIZ, L. P. N.; VASCONCELOS, L, J. E.; BOTTINO, M. A. \& MACIEL, L. C. Microhardness and diametral compression strength of single fill composite. Int. J. Odontostomat., 15(1):293-299, 2021.

ABSTRACT: To evaluate Knoop microhardness and diametral compression strength at different polymerization times. A total of 80 cylindrical samples with Filtek resin ${ }^{\mathrm{TM}}$ One Bulk Fill were made to perform the in vitro study, using half of total samples $(n=40)$ for each test and divided equally between groups $(n=10)$. All samples were made according to ISO 4049 using $2 \mathrm{~mm}$ thickness Teflon matrix and a central orifice with $4 \mathrm{~mm}$ diameter. Four different times of light-curing in Standard mode suggested by the light-unit manufacturer were selected, therefore, group 1 samples (G1) were light-cured for 5 seconds; group 2 (G2) for 10 seconds; group 3 (G3) for 15 seconds, and group 4 (G4) for 20 seconds. A radiant display, which means a power in $\mathrm{mW} / \mathrm{cm}^{2}$ by time in seconds was expressed in Joules $(\mathrm{J})$. The samples were stored in a dark container with distilled water at a temperature of $37^{\circ} \mathrm{C}$ for 48 hours before testing. One-way analysis of variance (ANOVA) with T-Test (LSD) of multiple comparisons of the mean values of Knoop hardness and diametral compression strength was performed, with significance index $\alpha=0.05$. Regarding the Knoop microhardness test, G1 (35.73 \pm 6.2) presented the lowest values, followed by G2, while G3 and G4 did not present statistical differences between them. For the diametral compression test, G1 (1387.76 \pm 190.51) obtained the lowest value when compared to the other groups. G2, G3, and G4 did not present significant statistical differences. The different polymerization times influenced the Knoop microhardness and the diametral compression strength of Bulk Fill resin.

KEY WORDS: composite resins; hardness; stress, mechanical; physical properties.

\section{INTRODUCTION}

The development of light cured composite resins marked the modern era of restorative dentistry. The evolution in the mechanical properties of direct composites, as well as the improvement of light-curing devices provided the use of these materials with a wide range of treatments.
Restoration fractures are still constantly pointed out as causes of failures, even if these materials have undergone great evolution. Polymerization, the relationship of the resin with the quantity and size of particles are factors that are linked to such fractures, and can influence the compressive strength of the

\footnotetext{
${ }^{1}$ Department of Dentistry and Prosthodontics, Faculdade Multivix, Vitória - ES, Brazil.

${ }^{2}$ Department of Dentistry, Santa Teresa - ES, Brazil.

${ }^{3}$ Department of Dental Materials and Prosthodontics, São Paulo State University (Unesp), Institute of Science and Technology, São José dos Campos - SP, Brazil.

${ }^{4}$ Department of Implantology and Prosthodontics, College of Dentistry CECAPE, Juazeiro do Norte, CE, Brazil.
} 
DE JESUS, R. H.; LAGE, K. S.; DALBONI, V. C.; DELBONI, O. L.; MATOS, J. D. M.; NAKANO, L. J. N.; ORTIZ, L. P. N.; VASCONCELOS, L, J. E.; BOTTINO, M. A. \& MACIEL, L. C. Microhardness and diametral compression strength of single fill composite. Int. J. Odontostomat., 15(1):293-299, 2021.

materials (Alkhudhairy \& Vohra, 2016). The search for the improvement of these materials, or even to simplify their use points out those developments has still been a great challenge (Monterubbianesi et al., 2016).

Due to its mechanical properties, aesthetics, easy handling, short polymerization time, composite resin becomes the material of choice for restorations. The incremental technique requires a delicate and rigorous technique from the professional, as it requires increments of a maximum of $2 \mathrm{~mm}$ in the cavities of the dental elements (Son et al., 2017). However, they are materials that, even following a strict protocol, can cause failures in restorations due to possible "gaps" formed between the layers (Shibasaki et al., 2017).

Camphorquinone is a photo initiator that reacts with an amine reducing agent and upon reaching the specific wavelength of light it becomes activated, resulting in the formation of free radicals, in which the polymerization of the resin begins. Full polymerization is an important factor in the use of light cured composites, but it is still considered a challenge in clinical practice (Al Shaafi et al., 2011).

For better adaptation of the material into the cavity and reduction of the clinical time, Bulk Fill or single-fill resins were introduced to the market. Increments can be inserted uniquely into the cavity, up to $5 \mathrm{~mm}$ thick, which makes them an alternative to conventional restorative treatment (Tsujimoto et al., 2017). In addition to simplifying procedures, due to the shorter clinical time, Bulk Fill resins provide better wellbeing for both patients and dentists (Tsujimoto et al.).

Single-fill resins propose a reduction of the polymerization shrinkage and a greater depth without the need to increase the irradiation time, and allows the filling of dental cavities in larger layers, from $4 \mathrm{~mm}$ to $5 \mathrm{~mm}$ thick (Pereira et al., 2018; Shimokawa et al., 2018). These composites can be light-cured in thicker layers with low polymerization shrinkage and good mechanical properties, because Bulk Fill resins are translucent (Fronza et al., 2017).

Several factors can influence the mechanical properties of composite resin (CR), among them: compressive strength, increment size, diametric stress resistance, microhardness, composition and even different polymerization times. Thus, this study evaluated the influence of different times on the polymerization of Bulk Fill resin in some of its physical properties.

\section{MATERIAL AND METHOD}

Study Design. This study was an experimental research, in which the factor under study was the light curing time (at four levels). Having as variable the response to Knoop microhardness, measured in Kilograms/force per square millimeter $\left(\mathrm{Kgf} / \mathrm{mm}^{2}\right)$ and the diametral compression strength measured in Newtons $(\mathrm{N})$, both of a quantitative nature as shown in Figure 1.

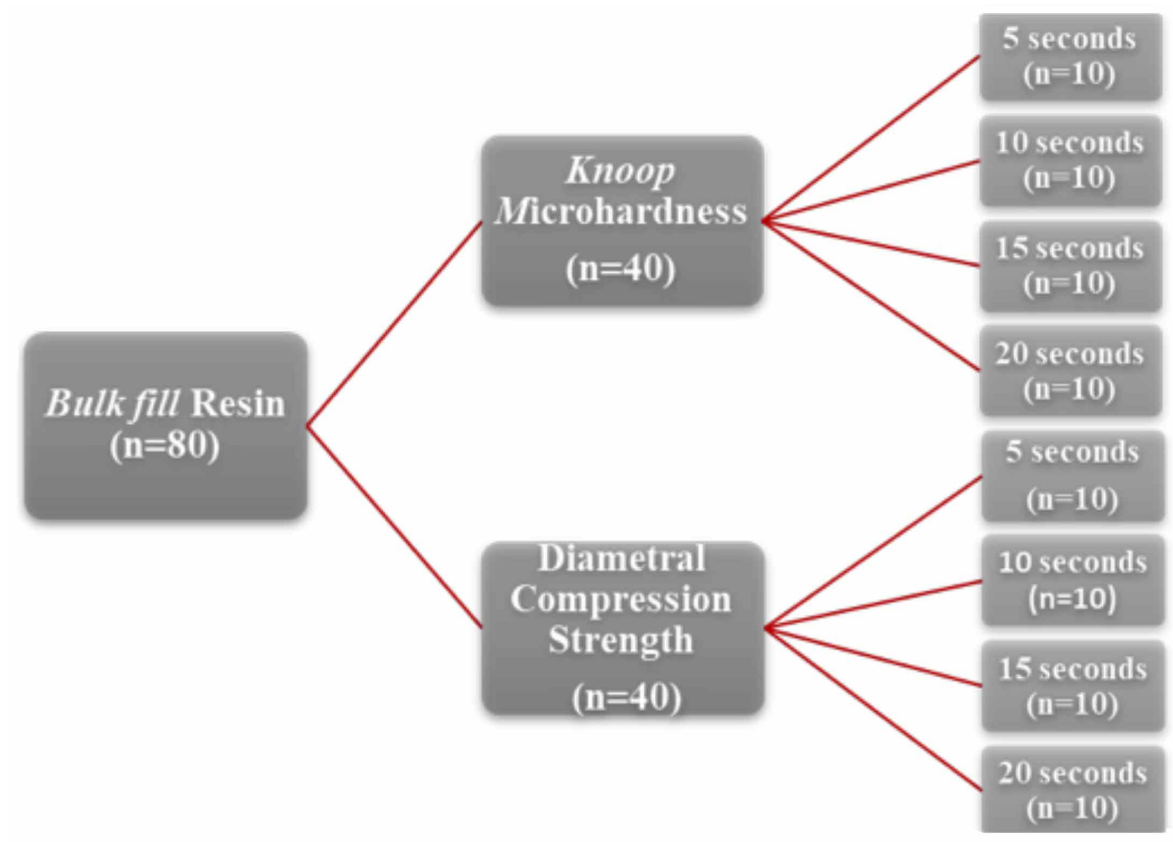

Fig. 1. Experimental design. 
DE JESUS, R. H.; LAGE, K. S.; DALBONI, V. C.; DELBONI, O. L.; MATOS, J. D. M.; NAKANO, L. J. N.; ORTIZ, L. P. N.; VASCONCELOS, L, J. E.; BOTTINO, M. A. \& MACIEL, L. C. Microhardness and diametral compression strength of single fill composite. Int. J. Odontostomat., 15(1):293-299, 2021.

Sample Making. A total of 80 cylindrical samples with Filtek resin ${ }^{\mathrm{TM}}$ One Bulk Fill were prepared to perform this in vitro study (3M ESPE, St. Paul, MN, EUA) (Table I), using half $(n=40)$ for each test performed and divided equally between groups $(n=10)$. Teflon matrix of $2 \mathrm{~mm}$ thickness and a central orifice with $4 \mathrm{~mm}$ of diameter were used following the norms of ISO 4049 (International organization for standardization, 2009). All samples were standardized and checked with a thickness gauge (Golgran dental instruments, São Caetano do Sul, Brazil).
On a black background, a glass plate and a transparent polyester matrix (Fava, São Paulo, SP, Brazil) were placed, followed by the Teflon matrix and thus filled in a single increment with the aid of a composite resin spatula Suprafill 1 (Golgran dental instruments, São Caetano do Sul, Brazil). Afterwards, a new polyester matrix and glass slide were placed on the filled set. The entire set was maintained with digital pressure for 10 seconds for homogenization (Fig. 2) and flattening the surface of the Bulk Fill resin (Fig. 3).

Table I. Filtek Resin ${ }^{\mathrm{TM}}$ One Bulk Fill characteristics.

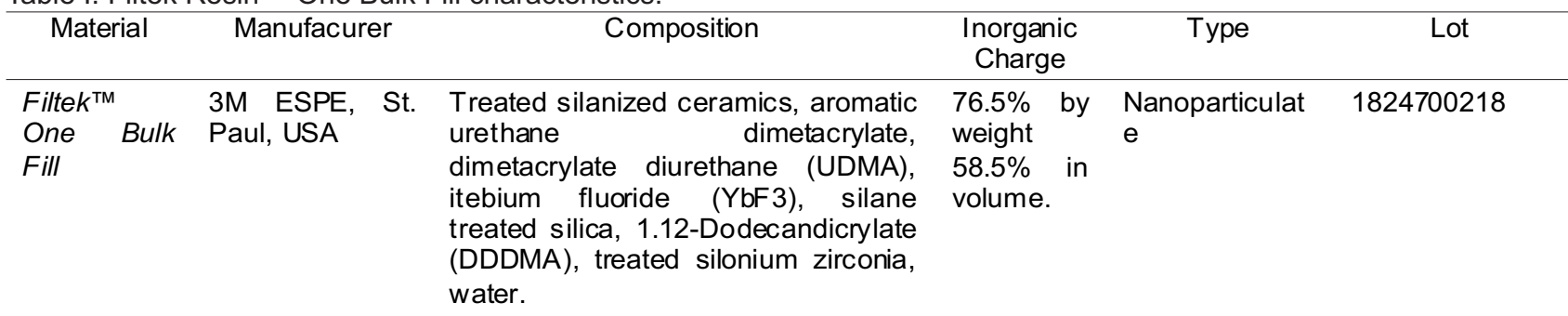

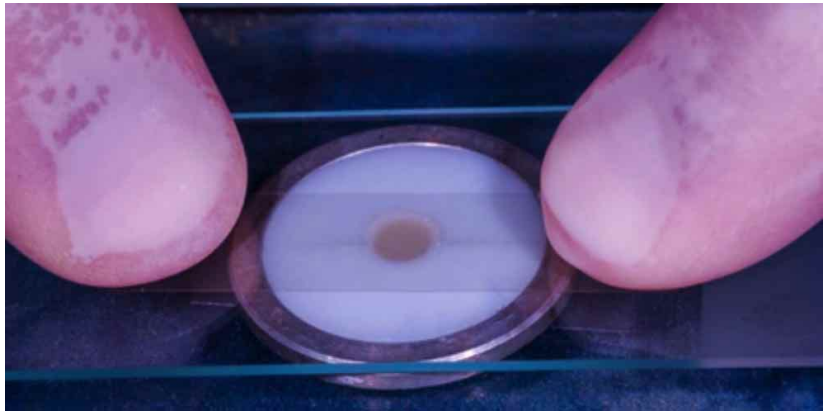

Fig. 2. Homogenization of Bulk Fill resin.

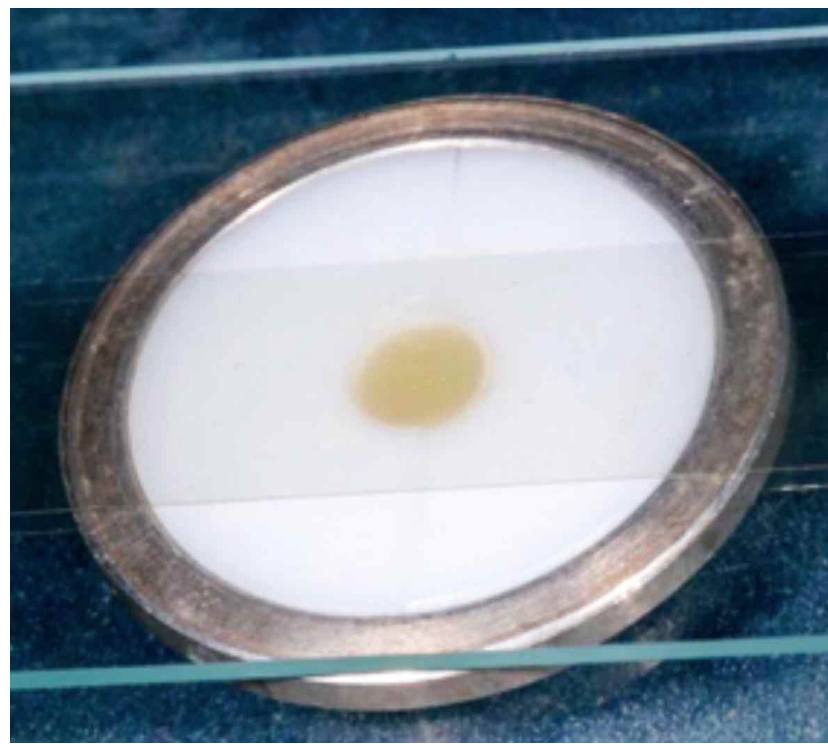

Fig. 3. Planning the resin increment on the teflon matrix.
The Valo diode (LED) photoactivator emitting light source (LED) (Ultradent, South Jordan, UT 84095 , United States) with the $10 \mathrm{~mm}$ diameter circular shaped light outlet tip was used for the polymerization of all samples. The light-curing in Standard mode was used with irradiance energy of $1000 \mathrm{~mW} / \mathrm{cm}^{2}$ which was suggested by the light-unit manufacturer (Fig. 4).

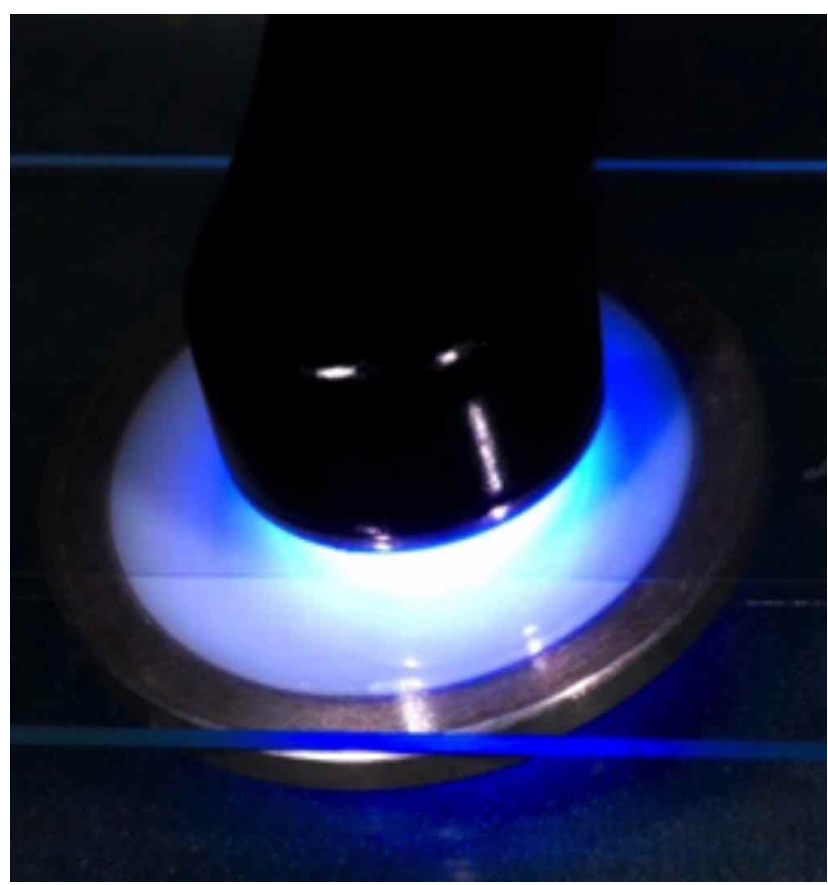

Fig. 4. Bulk Fill resin light curing. 


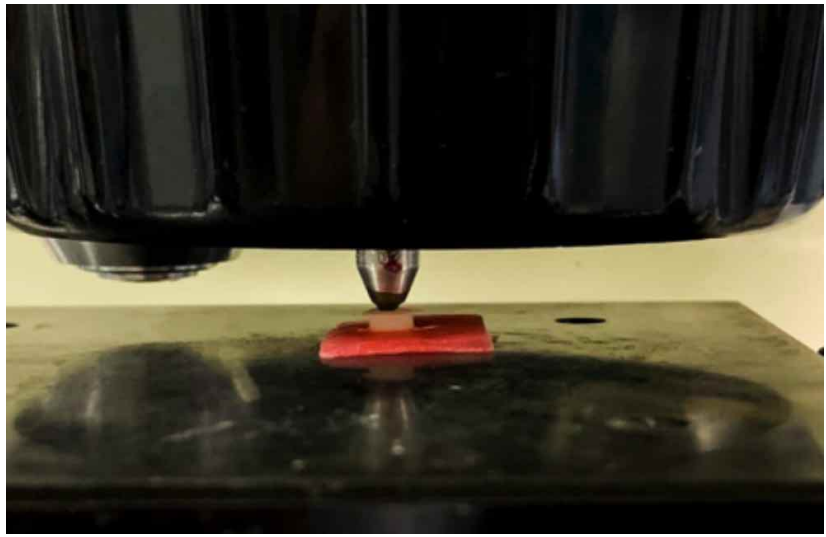

Fig. 5. Knoop microhardness test.

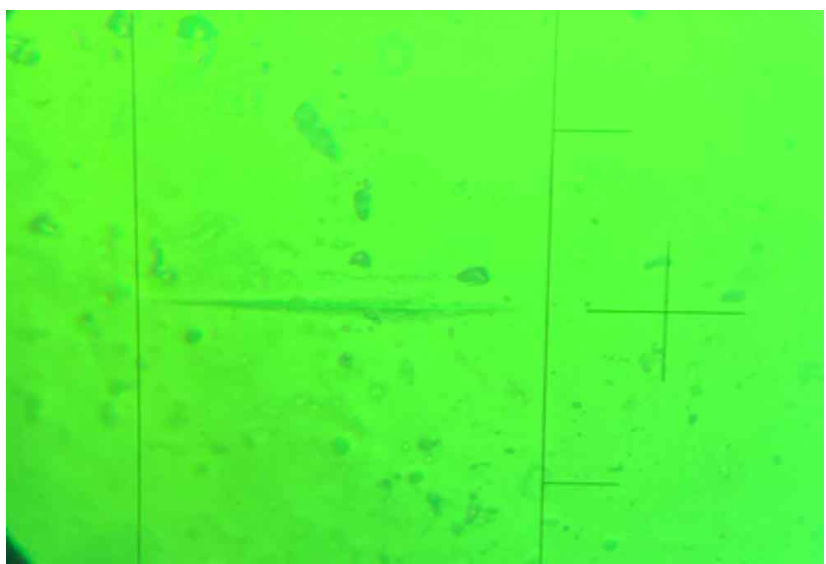

Fig. 6. Photomicrography of indentation.

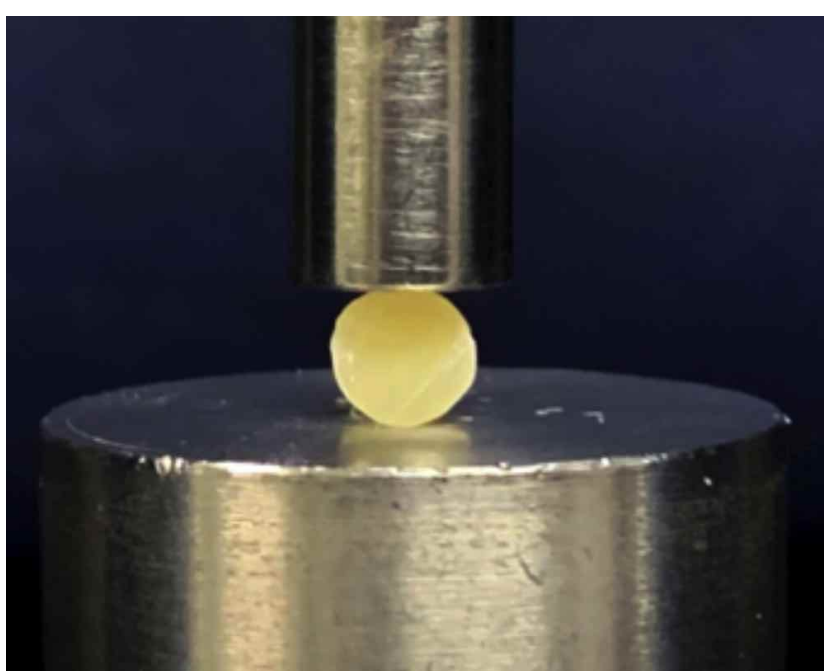

Fig. 7. Diametral Compression Test.

Hence, the samples from group 1 (G1) were photopolymerized for 5 seconds; group 2 (G2) for 10 seconds; group 3 (G3) for 15 seconds, and group 4 (G4) for 20 seconds. The radiant exposure, which means the power in $\mathrm{mW} / \mathrm{cm}^{2}$ times the time in seconds, was expressed in Joules (J). Soon after photo activation, the samples were stored in a dark container with distilled water in a laboratory oven at a temperature of $37^{\circ} \mathrm{C}$ for 48 hours.

Microhardness Test. The Knoop hardness values were measured at the top in regions of the sample that did not present porosity/bubbles, using the HMV 2000 digital microdurometer device (Shimadzu, Tokyo, Japan) with $50 \mathrm{~g}$ load calibration applied during 10s (Fig. 5). Three indentation regions were demarcated, making a total of 10 measurements per group (Fig. 6).

The values obtained in micrometers were converted into the number of Knoop microhardness $\left(\mathrm{KHN}-\mathrm{Kgf} / \mathrm{mm}^{2}\right)$, by the device's software. For each sample, the average of the three indentations was obtained

Diametral Compression Tests. The test was performed using a Universal Testing Machine (EMIC DL2000, São José dos Pinhais, PR, Brazil), coupled to a $10 \mathrm{~mm}$ diameter rod with a flat end. The positioning of the specimens was in the center of the rod, which exerted diametral compression force at a speed of $1 \mathrm{~mm} /$ minute towards the base of the device until the material failure (Fig. 7). The collected data recorded the maximum compression force in Newtons (N).

Statistical Analysis. The results were tabulated and analyzed using the Bioestat Software 5.3 (Federal University of Pará, Belém, Brazil) showing normal and homogeneous distribution. Variance analysis (ANOVA) of a criterion with T-Test (LSD) of multiple comparisons of the mean values of both Knoop microhardness and diametral compression strength with significance index $\alpha=0.05$ was performed.

\section{RESULTS}

The results obtained are shown in Table II. The Knoop microhardness test, G1 (35.73 \pm 6.2$)$ presented the lowest values $p<0.001$, followed by $G 2$, while G3 and G4 did not present statistical differences between them $p>0.05$. For the diametral compression test, $\mathrm{G} 1(1387.76 \pm 190.51)$ obtained the lowest value when compared to the other groups $p<0.001$. G2, G3, and G4 did not present significant statistical differences $p>0.05$. 
DE JESUS, R. H.; LAGE, K. S.; DALBONI, V. C.; DELBONI, O. L.; MATOS, J. D. M.; NAKANO, L. J. N.; ORTIZ, L. P. N.; VASCONCELOS, L, J. E.; BOTTINO, M. A. \& MACIEL, L. C. Microhardness and diametral compression strength of single fill composite. Int. J. Odontostomat., 15(1):293-299, 2021.

Table II. Knoop microhardness and diametral compression test. Average \pm standard deviation

\begin{tabular}{lcc}
\hline & $\begin{array}{c}\text { Knoop microhardness } \\
\text { test (Kgf/mm_) }\end{array}$ & $\begin{array}{c}\text { Diametral } \\
\text { compression test (N) }\end{array}$ \\
\hline G1 $5 \mathrm{~J} / \mathrm{cm}^{2}$ & $35,73 \pm 6,2^{\mathrm{C}}$ & $1387,76 \pm 190,51^{\mathrm{B}}$ \\
G2 $10 \mathrm{~J} / \mathrm{cm}^{2}$ & $49,66 \pm 6,1^{\mathrm{B}}$ & $1552,51 \pm 226,71^{\mathrm{A}}$ \\
G3 $15 \mathrm{~J} / \mathrm{cm}^{2}$ & $58,22 \pm 6,4^{\mathrm{A}}$ & $1664,62 \pm 164,11^{\mathrm{A}}$ \\
G4 $20 \mathrm{~J} / \mathrm{cm}^{2}$ & $63,68 \pm 8,3^{\mathrm{A}}$ & $1709,59 \pm 164,65^{\mathrm{A}}$ \\
\hline
\end{tabular}

ANOVA of a criterion and T-Test (LSD). Different letters indicate statistical difference $p>0.05$. aminobenzoate) and UDMA (Diuretanodimethcrycrycrylate) (Lima et al., 2019; Rizzante et al., 2019; Tauböck et al., 2019). In this line of reasoning Zorzin et al. (2015) report that the association of Bis-GMA monomers with UDMA or TEGDMA will increase the degree of conversion, creating a network of highly rigid polymers, which consequently increase the polymerization of the resin at depths.

The incorporation of new photoinitiators influences the resin curing process, such as increasing its ability to transfer light at its depths (Gomes et al., 2018; llie, 2019). Filtek resin ${ }^{\mathrm{TM}}$ One Bulk Fill has unique monomers in its composition, additional fragmentation (AFM) and aromatic dimethacrylate urethane (AUDMA) (Bucuta \& Ilie, 2014). Therefore, this explains why the resin does not present statistically significant differences in groups 2, 3, and 4 in the diametral compression test, as the monomers were introduced to reinforce the initiation, as it has satisfactory characteristics regarding the regularization of polymerization, and its ability to deeply polymerize single-fill materials.

Similar results were obtained in previous studies conducted by Farahat et al., where they evaluated two Bulk Fill resins at different polymerization times, 20 and $40 \mathrm{~s}$, and observed that by increasing the polymerization time, they obtained a significantly higher result on the degree of conversion of the samples. However, the success of using Bulk Fill resins is linked to exposure time.

The statistical differences observed in the Knoop microhardness test, where Group 1 (35.73 \pm 6.2) obtained lower results, which can be answered due to the polymerization being only at the top of the sample. Obtaining similarity in the study by Karacolak et al. (2018), which evaluated 11 resins, and all groups, radiant energy decreased with increasing thickness. And found no significant difference at the top of the samples.

In order to compare the mechanical properties and the degree of polymerization of Bulk Fill resins, Czasch \& Ilie (2013) observed that there were no improvements in increasing the polymerization time from 20 to $40 \mathrm{~s}$ in composites of $4 \mathrm{~mm}$. This can be explained due to the characteristics of the material, as well as high-power light-curing devices positively interfere in the polymerization process of composites. 
This study obtained statistically significant results in the Knoop microhardness test, since the polymerization of the material occurred only at the top, due to the samples having a thickness of $2 \mathrm{~mm}$, with no need for polymerization at the bottom, since the light from the high-power photopolymerizer would penetrate to the bottom of the samples. In contrast, Son et al. state that polymerization at the top in Knoop microhardness measurements did not have different results, but when different thicknesses of the samples were compared at the bottom 2, 4 and $6 \mathrm{~mm}$ they obtained different results.

Another factor considered critical in relation to the polymerization of Bulk Fill resins, is the radiant energy fully received by there $\left(\mathrm{J} / \mathrm{cm} \sum\right)$, because the low exposure to photons will result in a low polymerization. This joint polymerization at the bottom and top of the restorations becomes more important (Van Ende et al., 2017; Karacolak et al.; Romão et al., 2018; Peixoto et al., 2019; Veloso et al., 2019). Contrary to Knoop microhardness results of this study, in which it occurred only at the top of the samples, because the reduction in stages of the hardness in the resin matrix body also decreases the degree of conversion of the composites.

Corroborating with obtained results, Lima et al. (2018) analyzed the polymerization depth of Bulk Fill resins, where the radiant energy of $20 \mathrm{~J}$ obtained greater similarity and satisfactory results in the analyzed studies. That is, the total energy dose is influenced by the irradiance offered.

It is evident, therefore, that despite having monomers that favor the degree of conversion of Bulk Fill resins, insufficient amounts of irradiating energy can negatively influence some physical properties of these composites. Given the technical limitations for performing this work, the measurement of microhardness in the bottom of samples when at depths greater than $2 \mathrm{~mm}$, can be suggest for future studies.

\section{CONCLUSION}

It can be concluded from this study that: The different polymerization times influenced the Knoop microhardness of the tested Bulk Fill resin. In addition, the different polymerization times influenced the diametral compression strength.
DE JESUS, R. H.; LAGE, K. S.; DALBONI, V. C.; DELBONI, O. L.; MATOS, J. D. M.; NAKANO, L. J. N.; ORTIZ, L. P. N.; VASCONCELOS, L, J. E.; BOTTINO, M. A. \& MACIEL, L. C. Microdureza y resistencia a la compresión diametral de resina compuesta mono incremental. Int. J. Odontostomat., 15(1):293-299, 2021.

RESUMEN: El objetivo de este trabajo fue evaluar la microdureza Knoop y la resistencia a la compresión diametral en diferentes tiempos de polimerización. En el estudio realizado in vitro, se analizó un total de 80 muestras cilíndricas con la resina Filtek ${ }^{\mathrm{TM}}$ One Bulk Fill, utilizando la mitad $(\mathrm{n}=40)$ para cada prueba realizada y dividida en partes iguales entre los grupos $(n=10)$. Todas las muestras se tomaron de acuerdo con ISO 4049 utilizando matrices de teflón de $2 \mathrm{~mm}$ de espesor y orificio central con $4 \mathrm{~mm}$ de diámetro. Se seleccionó cuatro veces el fotocurado de manera estándar, sugerido por el fabricante. Por lo tanto, las muestras del grupo 1 (G1) se fotopolimerizaron durante 5 segundos; grupo 2 (G2) durante 10 segundos; grupo 3 (G3) durante 15 segundos y grupo 4 (G4) durante 20 segundos. La exposición radiante, que indica la potencia en $\mathrm{mW} /$ $\mathrm{cm}^{2}$ a lo largo del tiempo en segundos, se expresó en julios (J). Las muestras se almacenaron en un recipiente oscuro con agua destilada en una estufa a una temperatura de $37^{\circ} \mathrm{C}$ durante 48 horas antes del ensayo. Se realizó para comparaciones múltiples de los valores medios, análisis de varianza (ANOVA) de un criterio con la prueba T (LSD) tanto de la dureza de Knoop como de la compresión diametral con un índice de significación $\alpha=0.05$. Con respecto a la prueba de microdureza de Knoop, G1 $(35,73 \pm 6,2)$ tuvo los valores más bajos, seguido de G2, mientras que G3 y G4 no mostraron diferencias estadísticas entre ellos. Para la prueba de compresión diametral, G1 (1387.76 \pm 190.51) obtuvo el valor más bajo en comparación con los otros grupos. G2, G3 y G4 no presentaron diferencias estadísticamente significativas. Los diferentes tiempos de polimerización influyeron en la microdureza de Knoop y la resistencia a la compresión diametral de la resina compuesta mono incremental.

PALABRAS CLAVE: resinas compuestas, dureza, estrés mecánico, propiedades físicas.

\section{REFERENCES}

Abed, Y. A.; Sabry, H. A. \& Alrobeigy, N. A. Degree of conversion and surface hardness of bulk-fill composite versus incrementalfill composite. Tanta Dent. J., 12(2):71-80, 2015.

Al Shaafi, M.; Maawadh, A. \& Al Qahtani, M. Evaluation of light intensity output of QTH and LED curing devices in various governmental health institutions. Oper. Dent., 36(4):356-61, 2011.

Alkhudhairy, F. \& Vohra, F. Compressive strength and the effect of duration after photo-activation among dual-cure bulk fill composite core materials. Pak. J. Med. Sci., 32(5):1199-203, 2016.

Alkhudhairy, F. I. The effect of curing intensity on mechanical properties of different bulk-fill composite resins. Clin. Cosmet. Investig. Dent., 9:1-6, 2017.

Alrahlah, A. Diametral tensile strength, flexural strength, and surface microhardness of bioactive bulk fill restorative. J. Contemp. Dent. Pract., 19(1):13-9, 2018. 
Bucuta, S. \& Ilie, N. Light transmittance and micro-mechanical properties of bulk fill vs. conventional resin based composites. Clin. Oral Investig., 18(8):1991-2000, 2014.

Czasch, P. \& Ilie, N. In vitro comparison of mechanical properties and degree of cure of bulk fill composites. Clin. Oral Investig., 17(1):227-35, 2013.

Farahat, F.; Daneshkazemi, A. \& Hajiahmadi, Z. The effect of bulk depth and irradiation time on the surface hardness and degree of cure of bulk-fill composites. J. Dent. Biomater., 3:284-91, 2016.

Fronza, B. M.; Ayres, A.; Pacheco, R. R.; Rueggeberg, F. A.; Dias, C. \& Giannini, M. Characterization of inorganic filler content, mechanical properties, and light transmission of bulk-fill resin composites. Oper. Dent., 42(4):445-55, 2017.

Gomes, T. N.; Matos, J. D. M.; Vasconcelos, J. E. L.; Olivieri, K. A. N.; Brandt, W. C. \& Miranda, M. E. Effect of different photoiniciers of experimental adhesive systems on adhesive interface union resistance. Int. Arch. Med., 11(26):1-12, 2018.

Gonçalves, F.; Campos, L. M. P.; Rodrigues-Júnior, E. C.; Costa, F. V.; Marques, P. A.; Francci, C. E.; Braga, R. R. \& Boaro, L. C. C. A comparative study of bulk-fill composites: degree of conversion, post-gel shrinkage and cytotoxicity. Braz. Oral Res., 32:e17, 2018.

Ilie, N. Sufficiency of curing in high-viscosity bulk-fill resin composites with enhanced opacity. Clin. Oral Investig., 23(2):747-55, 2019.

International Organization for Standardization. ISO 4049. Polymer Based Filling Restorative and Luting Materials. 3rd ed. Geneva, International Organization for Standardization, 2009. Available from: https://www.iso.org/standard/42898.html

Karacolak, G.; Turkun, L. S.; Boyacioglu, H. \& Ferracane, J. L. Influence of increment thickness on radiant energy and microhardness of bulk-fill resin composites. Dent. Mater. J., 37(2):206-13, 2018.

Lima, E. A.; Filgueira, P. T. D.; Santos, J. B. M. D.; Oliveira, L. J. R. \& Braz, R. Physicomechanical and thermal analysis of bulk-fill and conventional composites. Braz. Oral Res., 33:e008, 2019.

Lima, R. B. W.; Troconis, C. C. M.; Moreno, M. B. P.; Murillo-Gómez, F. \& De Goes, M. F. Depth of cure of bulk fill resin composites: A systematic review. J. Esthet. Restor. Dent., 30(6):492-501, 2018.

Monterubbianesi, R.; Orsini, G.; Tosi, G.; Conti, C.; Librando, V.; Procaccini, M. \& Putignano, A. Spectroscopic and mechanical properties of a new generation of bulk fill composites. Front. Physiol., 27(7):652, 2016.

Peixoto, N. M.; Matos, J. D. M.; Andrade, V. C.; Bottino, M. A. \& Zogheib, L. V. Evaluación de la resistenciade unión de brackets ortodónticos fijados a cerámica de disilicato de litio. Int. J. Odontostomat., 13(2):207-18, 2019.

Pereira, A. L. C.; Matuda, L. S. A.; Lima, L. G.; Silva, M. F. L.; MoraisSousa, L. K.; Matos, J. D. M.; Vasconcelos, J. E. L. \& Medeiros, C. R. Evaluation of thefluorescence of composite resins under an ultra violet light source. Int. J. Odontostomat., 12(3):252-61, 2018.

Rizzante, F. A. P.; Duque, J. A.; Duarte, M. A. H.; Mondelli, R. F. L.; Mendonça, G. \& Ishikiriama, S. K. Polymerization shrinkage, microhardness and depth of cure of bulk fill resin composites. Dent. Mater. J., 1;38(3):403-10, 2019.

Romão, R. M.; Lopes, G. R. S.; Matos, J. D. M.; Lopes, G. R. S.; Vasconcelos, J. E. L. \& Fontes, N. M. Causes of failures in ceramic veneers restorations: A literature review. Int. J. Adv. Res., 6(4):896-906, 2018.

Shibasaki, S.; Takamizawa, T.; Nojiri, K.; Imai, A.; Tsujimoto, A.; Endo, H.; Suzuki, S.; Suda, S.; Barkmeier, W. W.; Latta, M. A. \& Miyazaki, M. Polymerization behavior and mechanical properties of high-viscosity bulk fill and low shrinkage resin composites. Oper. Dent., 42(6):E177-87, 2017.

Shimokawa, C. A. K.; Turbino, M. L.; Giannini, M.; Braga, R.R. \& Price, R. B. Effect of light curing units on the polymerization of bulk fill resin-based composites. Dent. Mater., 34(8):1211-21, 2018.
Son, S. A.; Park, J. K.; Seo, D. G.; Ko, C. C. \& Kwon, Y. H. How light attenuation and filler content affect the microhardness and polymerization shrinkage and translucency of bulk-fill composites? Clin. Oral Investig., 21(2):559-65, 2017.

Tauböck, T. T.; Jäger, F. \& Attin, T. Polymerization shrinkage and shrinkage force kinetics of high- and low-viscosity dimethacrylateand ormocer-based bulk-fill resin composites. Odontology, 107(1):103-10, 2019.

Tsujimoto, A.; Barkmeier, W. W.; Takamizawa, T.; Latta, M. A. \& Miyazaki, M. Depth of cure, flexural properties and volumetric shrinkage of low and high viscosity bulk-fill giomers and resin composites. Dent. Mater. J., 36(2):205-13, 2017.

Veloso, S. R. M.; Lemos, C. A. A.; de Moraes, S. L. D.; do Egito Vasconcelos, B. C.; Pellizzer, E. P. \& de Melo Monteiro, G. Q. Clinical performance of bulk-fill and conventional resin composite restorations in posterior teeth: a systematic review and metaanalysis. Clin. Oral Investig., 23(1):221-33, 2019.

Zorzin, J.; Maier, E.; Harre, S.; Fey, T.; Belli, R.; Lohbauer, U.; Petschelt, A. \& Taschner, M. Bulk-fill resin composites: polymerization properties and extended light curing. Dent. Mater., 31(3):293-301, 2015.

\section{Corresponding author:}

Jefferson David Melo de Matos

Department of Dental Materials and Prosthodontics

São Paulo State University (Unesp)

Institute of Science and Technology

São José dos Campos - SP,

BRAZIL

Avenue Engenheiro Francisco José Longo

777/778, Jardim São Dimas

São José dos Campos - SP

CEP: 12245000.

ORCID: https://orcid.org/0000-0003-4507-0785

E-mail: matosjefferson19@gmail.com 